\title{
USING MIND MAPS TO DEVELOP EFL PREPARATORY STAGE PUPILS' ENGLISH READING COMPREHENSION SKILLS Amany Abd El-Hameed Mohamed Khalifa
}

\begin{abstract}
The present study aimed at investigating the effectiveness of using mind maps strategy in developing EFL preparatory stage pupil's reading comprehension skills. To achieve the purpose of the study, one instrument was designed and conducted by the researcher. A prepost reading comprehension test was administrated to assess the pupils' reading comprehension skills level before and after being exposed to the treatment. The study adopted the quasi-experimental design. The participants of the study consisted of 80 female pupils randomly chosen from EFL first year preparatory stage pupils in Girls Preparatory School in Belqas. They were randomly assigned into two groups: the experimental group was exposed to mind maps strategy and one control group received the convential teaching following the prescribed Teacher's Guide procedures. Results of the study revealed that using mind maps were substantially effective in developing EFL pupil's reading comprehension skills. A number of recommendations concerning the use of mind maps were presented.
\end{abstract}

Keywords: mind maps, reading comprehension \section{Introduction: \\ Reading is regarded as one of the} language major and basic skills that learners should master to become lifelong learners. It is a mental activity that stimulates the development of brain cells and helps the mind grows in its ability. In the past, reading was viewed as a static activity. General meaning was embedded in the text, and the reader's role was to understand what was being transmitted through the words in the text. Recently, reading is viewed as a more dynamic process in which the reader constructs meaning based on the information he /she gets from the text (Robel \& Shiue, 2013). Many scholars consider reading a constructive process. Wade viewed reading as the active construction of meaning, and McGeown and Getilucci (2007, p.136) described reading as a covert process actively controlled by readers to create meaning from text (Ebrahimil, 2012).

Reading is viewed as a cognitive process of decoding symbols, letters, words and sentences to derive meaning from the text. It is like opening the door of understanding to individuals through opening up the whole new world of information to them. It is a communication process of sharing ideas and information between the reader and the writer. The ability to read is a crucial skill to achieve educational and professional success in life. It helps learners to learn from human knowledge and experience and to absorb new experience and replace old views (Romea, 2015 and Pranata \& Junining, 2015). Reading also enables learners to develop other language skills and increase their vocabulary.

According to Suryani (2015), reading includes beliefs emotions and human brain, as Weaver (2009) described "Reading is a process which is very much determined by what the reader's brain, emotions and beliefs bring to the reading: the knowledge/information (or misinformation, absence of information), strategies for processing text, moods, fears and joys-all of it."

There are hundreds reading strategies available to help students with their comprehension at different levels and with different types of text (Prado \& Plourde, 2005 cited in Harvey, 2013). One problem with strategy use is that it is often 
not taught explicitly enough or it is taught incorrectly.

\section{Reading comprehension}

Reading is the foundation for lifelong learning. However, it is simply not enough for learners. They must be able to understand what they read and apply the newly acquired knowledge for the benefits to be fully realized (Manning, 2003). The primary purpose of reading is comprehension. Comprehension is an essential component of reading process. It is what reading is all about because gaining meaning and developing a means for retaining the information are regarded as one of the ultimate objectives of reading (Jacobs, 2002).

Reading comprehension is the act of constructing meaning from the text through the interaction between the text and the reader and it involves the orchestration of the readers' prior knowledge about the world and about the language. Reading comprehension skills are essential for learners to read proficiently, learn effectively and to conceptualize (Robel \& Shiue, 2013). Reading comprehension is impeded by students' lack of background knowledge, experience, purpose for reading a text and their inability to use effective comprehension strategies to combine information from the text with their background knowledge. Therefore, teachers can greatly increase their student's reading comprehension skills by using suitable teaching strategies and methods. Students must grow into independent learners; the role of the teacher is in ongoing professional growth to facilitate the transfer of knowledge that makes this goal possible (Chang, Sung \& Chen, 2002 cited in Ellozy \& Mostafa, 2010).

Salehi,

Khodabandehlou investigating the effectiveness of concept map on developing reading comprehension ability of EFL students. The participants were 80 (40 males and 40 females) EFL students. A pretest including reading comprehension test was administered to measure the students' comprehension ability before applying the treatment. The experimental group student's were taught using the concept map and those of the control group were instructed using the traditional methods of teaching reading comprehension. Both the classes of the two groups were met two sessions per week lasted for seven weeks. The findings of the study revealed that there are a significant effectiveness of applying the concept map on developing reading comprehension ability of students.

Choo, Eng and Ahmad (2011) investigated the effects of reciprocal teaching strategies on reading comprehension. The participants were four Sixth-Form, intact classes among 68 lowproficiency students. The study conducted the quasi-experimental design. An intervention of nine reading lessons using reciprocal teaching strategies was administered over a period of one month. The instruments used for collecting data were a pre test, a post test and five openended questions given after the treatment. The results from the independent t-test and paired-sample t-tests indicated a significant difference showing the effectiveness of using reciprocal teaching strategies.

Khoshsima and Tiyar (2014) explored the effectiveness of using the summarizing strategy to enhance the Iranian intermediate EFL learners' reading comprehension. Sixty-one students were selected to participate in the study and randomly divided into the control and the experimental groups. A TOEFL proficiency test was used to establish the homogeneity of their proficiency level. All the students in the two groups participated a week typically 45 minutes in duration for ten weeks. An immediate post test was 
administered after each two week instruction. The post-test was administered at the end of the treatment to both of the groups the control and the experimental. It was found that summarizing strategy has a significant effect on the students' reading comprehension.

\section{Mind Maps}

There are various types of reading strategies that have been used by researchers to improve reading comprehension, these include visualization / imagery, inferring and graphic representation or mind mapping. Mind maps strategy is regarded as one of the various types of reading strategies that have been used by researchers to improve reading comprehension. Mind Maps are visual learning strategy for visualizing the relationships among different concepts, contains visual frameworks like figures, diagrams, or charts utilized to display with ideas branching into their subscales using key words, images, codes, symbols and colours. They assist students communicate information easily since they break the complexity of the text passage into words for easier understanding. Mind maps also clarify the complex concepts to simple and meaningful representations so that learners can develop a comprehensive comprehension of the content to be learnt in a visual map (Bayat \& Malekzadeh, 2015, Siriphanich, 2010 and Moi \& Lian, 2007).

Mind Maps are useful for organizing information and generating the ideas; however, they also create patterns, build connections, and establish associations between the learner's own experience and the new information. They use visual and spatial strategies rather than the linear strategies need for outlining. Mind Mapping is an open-ended structure that increases the rapid connection of thought patterns and provides immediate feedback (Williams, 2008).
Mind maps offer a means to make the invisible thinking and organization of the text visible. According to Tony Buzan, mind maps help students structure and order their thinking by creating a visual representation of concepts and their understanding. They also can be used to improve reading comprehension in both fiction and non-fiction texts, and across a variety of genres ("Mind mapping, 2011", Ardakani \& Lashkarian, 2015). Moreover, by using mind maps students can visualize relationship between ideas, create their own ideas and relate them, make connections between key ideas, comprehend and remember the information better.

The study of Bekti (2009) determined the effect of applying mind map to teach reading comprehension to the eleventh grade students of SMK Negeri 8 Semarang in the academic year of $2006 /$ 2007. 30 students were assigned as the experimental group and instructed by employing mind map, whereas other 30 students were taken as the control group and instructed without using mind map. Results of the study supported the significant difference between the students of the experimental group who were instructed by using mind map and those of the control group who were taught conventionally in the reading comprehension achievement infavor of the experimental group. Thus, mind map made a progress in teaching reading comprehension.

Cahyani, Asib and Rais (2015) conducted an action research to examine whether or not the application of mind mapping can improve reading comprehension and describing the class situation during presenting mind mapping. The seventh year students of SMP N 3 Colomadu were the participants in the study. Pre-observation, pre-test and posttest, interview and field note were used in 
the study. Data were collected and analyzed through using qualitative and quantitative method. Implementing mind mapping included two cycles. The results of the first cycle showed the problems in class situation and the researcher could overcome these problems in the second cycle. Finally, the main results indicated that the mind mapping was successful in improving the students' reading comprehension. Mind mapping also assisted students to get higher motivation and become more active in joining reading class. The students became better than before and their attitude towards English lesson particularly in reading class also progressed.

Kusmaningrum (2016) presented a study to apply mind map in improving reading comprehension and writing achievements. The sample were 40 semester students of English Education Study Program of STAIN Curup in 2013/ 2014 academic year. The students were chosen through utilizing a purposive sampling technique and they were equally divided into the experimental and the control groups. The study applied the quasi experimental method. A reading comprehension test, a writing test, and a questionnaire were used to collect data. The findings of the study revealed the significant improvement in students' reading comprehension and writing achievements. In addition, the significant differences in reading comprehension and writing achievements between the experimental group students who were taught through utilizing mind map and those who were not. The students also expressed positive feedback towards using mind map. To conclude, mind map improved the students' reading and writing achievement.

San Rizqiya (2013) carried out a study to observe the implementation of employing the mind mapping to develop students' reading comprehension. The participants of the study were 34 students of tenth grade of a senior high school in Bandung. Data were collected and analyzed qualitatively through three sources : 1- the students' mind maps completeness of the criteria that had been set before. 2- the teacher and observer observation. 3- an open-ended questionnaire fulfilled by the students and teacher and observer. The findings of this study discussed indicated that mind map succeeded to attract the students 'interest to read the text. It also succeeded to improve their reading comprehension in the form of generic structure. The students' reactions towards the mind map to comprehend the texts were categorized as good. The teacher and the observer noticed that the students did not chat with their mates or played their mobile. They asked questions to get more clear explanation and the teaching and learning process was conducive than usual.

Suryani (2015) presented an action research study to improve the reading skills of students through using mind map strategy in the process of reading, teaching and learning. The participants were 27 students of second grade class in SMA N 1 Kretek, Bantul, Yogyakarta. The research consisted of two cycles. observations, interviews, and documentations were used in this action research. Interview transcripts, photographs, field notes and students' portofolios were used to collect data which analyzed qualitatively. The findings of the study revealed that using mind map strategy improved the students' reading skills. Besides that the Students achieved improvements in finding the topic sentence, vocabulary mastery and paraphrasing sentence. Furthermore, by applying the mind map: (1) the students were engaged in the process of learning and teaching. (2) They were motivated to participate actively in the classroom activities. (3) Thus, they got more 
experiences and improved their
achievement.
Tabrizi and Esmaeili (2016) carried out a study to explore the effect of using mind map improving Iranian EFL learners' reading comprehension ability. The study adopted the quasi-experimental design. Pre-and post-tests were used to evaluate the students' reading comprehension. The findings of the study showed that incorporating mind map into teaching reading comprehension skills can enhance students' understanding of the text and improve their reading comprehension achievement.

Wirda, Sulaiman and Wahyudin (2014) conducted a study to explore the influence of utilizing mind map on improving reading comprehension. The participants were second year students of SMP Negeri 2 Kasimbar. They were chosen by cluster sampling technique. The study adopted the pre-experimental design. Data were gathered through the observation and tests; the pre-test and post-test to measure the students' reading comprehension before and after the treatment. Results of the study indicated that using mind mapping technique was effective and it improved the students' ability in reading comprehension.

Ardakani and Lashkarian (2015) conducted a study to discover whether or not the implementation of mind map can increase the students' ability in reading comprehension. The subjects were 35 Iranian Intermediate students from the second year students of Iranian classes that attended English institute in Tehran in order to learn English for communication and reading skills. Data were collected through administrating the pre- test, the post-test, the oral interview and the questionnaire. pre- and post- test were used to assess the students' reading comprehension. A questionnaire also was conducted in order to obtain information about teaching reading comprehension by the use of mind map technique in various aspects. Oral interviews to obtain more information about the students response towards using mind map technique in their reading comprehension. Results of the study revealed that mind map lead to improvements in reading comprehension.

\section{Statement of the problem:}

Based on the previous background, the researcher's observations and the results of the pilot study, the problem can be stated as follows: First year preparatory stage students have difficulties in EFL reading comprehension. So, they were in need of training in a new and active reading comprehension strategies to help them to be effective readers in learning process. Hence, the present study explored the effectiveness of using mind maps strategy to develop EFL reading comprehension skills of preparatory stage students.

Questions of the study:

The study attempted to answer the following main questions:

1. What are the major reading comprehension skills necessary for the $1^{\text {st }}$ year preparatory stage students?

2. What is the effectiveness of using mind maps in developing the English reading comprehension skills of $1^{\text {st }}$ year preparatory stage students?

Purpose of the study:

The study aimed at:

1- Identifying the necessary reading comprehension skills for $1^{\text {st }}$ year preparatory stage students.

2- Investigating the effectiveness of using mind maps to develop English reading comprehension skills of $1^{\text {st }}$ year preparatory stage students. 
Delimitations of the study:

This study was limited to:

- A sample of $1^{\text {st }}$ year female students of Belqas preparatory school for girls in Belqas, Dakahlia.

- Some reading comprehension skills necessary for EFL $1^{\text {st }}$ year preparatory stage students.

- Reading comprehension lessons from the textbook "New Hello!"

- The first term of the school year 2015-2016.

\section{Study hypotheses:}

The present study attempted to verify the following hypotheses at the 0.05 level of significance.

1- There is a statistically significant difference between the mean scores of the experimental and the control groups on the post administration of the English reading comprehension test in favor of the experimental group.

2- There is a statistically significant difference between the mean scores of the experimental group on the pre-post administration of the English reading comprehension test in favor of the post administration.

\section{Methods of the study:}

\section{The setting and the Participants:}

The Participants were a sample of first year public preparatory school students. Eighty first-year female students at Preparatory School for girls, Belqas, Dakahlia were chosen randomly to participate in the study. Forty participants were assigned randomly as the experimental group used mind maps strategy in teaching reading. The other remaining forty participants were assigned as the control group and received the traditional teaching. Both groups were from the same region, of the same age and had the same teacher.

\section{Design of the study:}

The present study adopted the quasi-experimental design. The design utilized in this study was the two groups pre-post treatment. The participants were divided into an experimental group and a control group, and were exposed to prepost test of reading comprehension skills. The experimental group skills and received the treatment through using mind maps to develop their reading comprehension the control group received the traditional method of teaching reading comprehension skills.

\section{Instruments}

The following instruments were designed and used by the researcher in the current study:

1- A reading comprehension skills questionnaire.

2- A pre - post reading comprehension skills test.

\section{Reading comprehension skills} questionnaire.

The questionnaire was designed for determining the most important reading comprehension skills needed for first year preparatory stage students. This questionnaire consisted of a list of reading comprehension sub-skills. These skills were highly important to be included in both the pre-post test and the program itself.

pre - post reading comprehension skills test.

A pre-post reading comprehension skills test was designed to measure and evaluate the EFL reading comprehension skills of the first year preparatory stage students. It was administrated at the beginning of the first semester of the academic year 2015-2016. It was once before the treatment of the program and once after applying the program to both experimental and control groups to measure the effectiveness of the program. The 
reading comprehension test involved two reading passages and they were taken from http://www.eslprintables.com. The test consisted of twenty-six questions cover mainly the twelve reading comprehension sub-skills.

\section{Definition of terms:}

\section{Mind Map:}

Buzan (2003) defined mind map as an expression of radiant thinking and therefore a natural function of the human mind. It is a powerful graphic technique which provides a universal key to unlocking the potential of the brain. The mind map can be applied to every aspect of life where improved learning and clearer thinking will enhance human performance.

Mind map is an effective diagram with the function of representing and organizing the relationship of ideas,words, tasks and other items connected to and arranged around a central key word or idea by branches and involves words, phrases, colors and visual images (Buzan, 2006, Deshatty \& Mokashi, 2013 cited in Yunus, Chien 2016).

The following definition is adapted to serve the purpose of the study:

Mind map is a powerful visual learning strategy that enables learners to visualize, organize, comprehend the information in a text through making connections between the ideas using key words, images, colours and branches that radiate out from a central idea illustrating details and associations in a non-liner graphical format.

\section{Reading Comprehension:}

Reading comprehension can be defined as the process of simultaneously extracting and constructing meaning through interaction and involvement with written language. It consists of three elements: the reader, the text and the activity or purpose for reading".(Snow, 2002).

van den Broek and Espin (2012) defined reading comprehension as a complex interaction among the automatic and strategic cognitive processes which enables the reader to create a mental representation of the text.

The following definition is adopted to serve the purpose of the study: Reading comprehension is a cognitive process that depends on the engagement and interaction between the reader and the text which the reader utilizes his / her prior knowledge to build up the meaning of the text using the appropriate strategy to achieve this purpose.

\section{Results and discussion}

The results of the study are statistically analyzed in terms of its hypotheses and they are discussed in the light of the theoretical background and related studies.

\section{The first hypothesis:}

There is a statistically significant difference between the mean scores of the experimental and the control groups on the post administration of the reading comprehension test in favor of the experimental group.

1. To test the first hypothesis, a t-test for independent samples was employed. Results are shown in table (1) as follows. 
Table (1) : Results of t-test of the control and experimental groups on the postadministration of the EFL Reading test

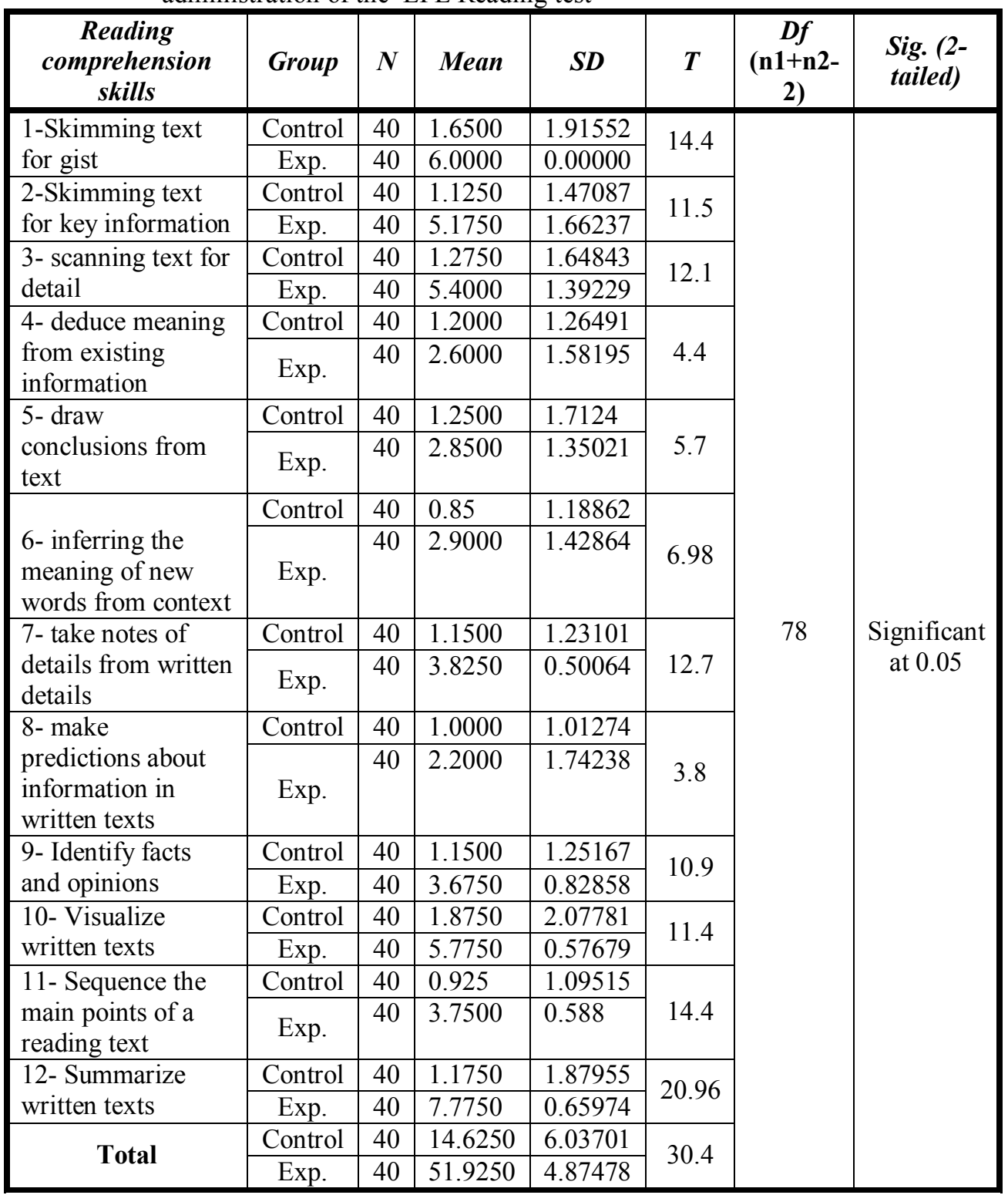

Table (1) shows that the mean scores of the experimental group students in the post administration of the EFL Reading test and in the total were higher than those of the control group. The table illustrates also the estimated $t$-value is significant at
.05 level. This indicates that there are statistically significant differences between the experimental and control group in the twelve sub-skills of the Reading comprehension and in the total score on the post-administration of the test. These 
significant differences are in favor of the experimental group. In other words, the experimental group outperformed the control group in their EFL Reading comprehension skills that were measured by the post administration of the Reading test.

\section{The second hypothesis:}

There is a statistically significant difference between the mean scores of the experimental group students' scores of the

Table (2): Results of t-test of the experimental group on the pre-post- administration of the Reading test

\begin{tabular}{|c|c|c|c|c|c|c|c|}
\hline $\begin{array}{c}\text { Reading } \\
\text { comprehension } \\
\text { skills }\end{array}$ & $\begin{array}{r}\text { Measure- } \\
\text { ment }\end{array}$ & $N$ & Mean & $S D$ & $T$ & $\begin{array}{r}D . f \\
(n-1)\end{array}$ & $\begin{array}{l}\text { Sig. (2- } \\
\text { tailed) }\end{array}$ \\
\hline \multirow{2}{*}{$\begin{array}{l}\text { 1-Skimming text for } \\
\text { gist }\end{array}$} & Pre & 40 & 1.9500 & 2.09945 & \multirow{2}{*}{12.2} & \multirow{26}{*}{39} & \multirow{26}{*}{$\begin{array}{r}\text { Significant } \\
\text { at } 0.05\end{array}$} \\
\hline & Post & 40 & 6.0000 & 0.0000 & & & \\
\hline \multirow{2}{*}{$\begin{array}{l}\text { 2-Skimming text for } \\
\text { key information }\end{array}$} & Pre & 40 & 1.7250 & 2.02532 & \multirow{2}{*}{9.9} & & \\
\hline & Post & 40 & 5.1750 & 1.66237 & & & \\
\hline \multirow{2}{*}{$\begin{array}{l}\text { 3- scanning text for } \\
\text { detail }\end{array}$} & Pre & 40 & 1.8000 & 1.77157 & \multirow{2}{*}{10.5} & & \\
\hline & Post & 40 & 5.4000 & 1.39229 & & & \\
\hline \multirow{2}{*}{$\begin{array}{l}\text { 4- deduce meaning } \\
\text { from existing } \\
\text { information }\end{array}$} & Pre & 40 & 1.2000 & 1.34355 & \multirow[b]{2}{*}{5.4} & & \\
\hline & Post & 40 & 2.6000 & 1.58195 & & & \\
\hline \multirow{2}{*}{$\begin{array}{l}\text { 5- draw conclusions } \\
\text { from text }\end{array}$} & Pre & 40 & 1.5000 & 1.33937 & \multirow{2}{*}{4.97} & & \\
\hline & Post & 40 & 2.8500 & 1.35021 & & & \\
\hline \multirow{2}{*}{$\begin{array}{l}\text { 6- inferring the } \\
\text { meaning of new } \\
\text { words from context }\end{array}$} & Pre & 40 & 1.1500 & 1.27199 & \multirow[b]{2}{*}{7.7} & & \\
\hline & Post & 40 & 2.9000 & 1.42864 & & & \\
\hline \multirow{2}{*}{$\begin{array}{l}\text { 7- take notes of } \\
\text { details from written } \\
\text { details }\end{array}$} & Pre & 40 & 1.0500 & 1.06096 & \multirow[b]{2}{*}{17.1} & & \\
\hline & Post & 40 & 3.8250 & 0.50064 & & & \\
\hline \multirow{2}{*}{$\begin{array}{l}\text { 8- make predictions } \\
\text { about information in } \\
\text { written texts }\end{array}$} & Pre & 40 & 1.1000 & 1.35495 & \multirow[b]{2}{*}{5.5} & & \\
\hline & Post & 40 & 2.2000 & 1.74238 & & & \\
\hline \multirow{2}{*}{$\begin{array}{l}\text { 9- Identify facts and } \\
\text { opinions }\end{array}$} & Pre & 40 & 1.0500 & 1.28002 & \multirow{2}{*}{13.02} & & \\
\hline & Post & 40 & 3.6750 & 0.82858 & & & \\
\hline \multirow{2}{*}{$\begin{array}{l}\text { 10- Visualize } \\
\text { written texts }\end{array}$} & Pre & 40 & 1.7250 & 1.90798 & \multirow{2}{*}{14.04} & & \\
\hline & Post & 40 & 5.7750 & 0.57679 & & & \\
\hline \multirow{2}{*}{$\begin{array}{l}11-\text { Sequence the } \\
\text { main points of a } \\
\text { reading text }\end{array}$} & Pre & 40 & 1.5250 & 1.32021 & \multirow[b]{2}{*}{11.3} & & \\
\hline & Post & 40 & 3.7500 & 0.588 & & & \\
\hline \multirow{2}{*}{$\begin{array}{l}\text { 12- Summarize } \\
\text { written texts }\end{array}$} & Pre & 40 & 1.1250 & 1.97663 & \multirow{2}{*}{21.5} & & \\
\hline & Post & 40 & 7.7750 & .65974 & & & \\
\hline \multirow{2}{*}{ Total } & Pre & 40 & 16.9000 & 5.42454 & \multirow{2}{*}{39.3} & & \\
\hline & Post & 40 & 51.9250 & 4.87478 & & & \\
\hline
\end{tabular}

pre and the post administrations of reading comprehension test in favor of the post administration.

To test the second hypothesis which addressed the difference between the mean scores of the experimental group students' scores of the pre and the post administration of the EFL Reading comprehension test , a t-test for independent samples was employed. Table (2) shows the results. 
Results in the above table illustrate that the estimated t-value is significant at 0.05 level. This reflects that there are statistically significant differences between the mean scores of the pre-postadministration of the EFL reading comprehension test in the twelve reading skills and in the total score. These significant differences are in favor of the post-test.

\section{Conclusions:}

The current study provided evidence for the effectiveness of implementing the training program based on using mind maps strategy in developing pupils' reading comprehension skills. The study showed that the students who exposed to mind maps outperformed students who exposed to the traditional method of teaching reading comprehension. Mind maps help them to comprehend the text better as they get used to using it and also paves the way for EFL learners to become skilled readers and cooperative learners. To conclude, based on the analysis of the study results and the discussion mentioned above, it can be concluded that using mind maps inside the Egyptian classrooms have a good impact on developing reading comprehension skills for preparatory stage students.

\section{Recommendations:}

Based on the results and conclusions, the following recommendations are suggested:

1. curriculum designers and specialists should consider the inclusion of mind maps in the EFL textbooks of preparatory stage students to help students read and comprehend well as well as to decrease the enormous quantity of information and concepts in English language.

2. Workshops and more training sessions should be held to train EFL teachers on how to use mind maps effectively inside the classroom in teaching reading to their students.

3. EFL teachers should not only depend on traditional methods of teaching like teachers' guide and text book activities; but also they should plan various reading activities that encourage students to use mind maps.

4. EFL researchers at curriculum and Instruction Departments in faculties of education should expand their research about the importance of using mind maps strategy in EFL classes as a new strategy for a whole language instruction.

\section{References}

1. Ardakani, M. P., \& Lashkarian, A. (2015). Using Mind Mapping Strategy to Improve Reading Comprehension Ability to Intermediate Iranian Student. Cumhuriyet Science Journal, 36(3), 1077-1095. Retrieved from:http://dergi.cumhuriyet.edu.tr/cu $\underline{\text { muscij/article/viewFile/5000118934/5 }}$ 000111235

2. Bayat, A.\& Malekzadeh, B.(2015). The Effect of Mind Mapping Strategy on Comprehending Implicit Information in EFL Reading Texts. International Journal of Educational Investigations, 2, ( 3), 81-90.

3. Bekti, S.(2009). Teaching Reading Comprehension Using Mind Mapping Technique. Doctoral dissertation, University of Negeri Semarang. Retrieved April 27, 2011 from: http://lib.unnes.ac.id/1884/

4. Buzan, T., \& Buzan, B. (2003). The mind map book: How to use radiant thinking to maximize your brain's untapped potential. Great Britain: Butler \& Tanner Ltd.

5. Cahyani, R.D, Asib, A.\& Rais, A.D (2015). Improving Students' Reading Comprehension Through Mind Mapping. JoLLIET, 2(1). Retrieved 
from:

http://download.portalgaruda.org/articl e.php?article $=354876 \& \mathrm{val}=8144 \&$ titl $\mathrm{e}=$ Improving $\% 20$ Students $\% \mathrm{C} 3 \% \mathrm{~A} 2 \%$ E2\%82\%AC\%E2\%84\%A2\%20Readi ng\%20Comprehension $\% 20$ Through $\%$ 20Mind\%20Mapping.

6. Choo, T. O. L., Eng, T. K., \& Ahmad, N. (2011). Effects of reciprocal teaching strategies on reading comprehension. Reading Matrix: An International Online Journal, 11(2). Retrieved from: https://pdfs.semanticscholar.org/6dd0/ 954e504dd00242fa7dffb9a23a67dc16 b0c5.pdf

7. Ebrahimil, S.S.(2012).A Comparison of Reading Strategies in Reading Poems by EFL Readers. International conference on Language, Medias and Culture, IPEDR 33, 99-104. Retrieved from: http://www.ipedr.com/vol33/020ICLMC2012-L10007.pdf

8. Ellozy, A. R., \& Mostafa, H. M. (2010). Making learning visible: Using e-maps to enhance critical reading skills. MERLOT Journal of Online Learning and Teaching, 6(3), 634-646. Retrieved September, 2010 from:

http://jolt.merlot.org/vol6no3/ellozy 0 910.pdf.

9. Harvey, M. (2012). Reading Comprehension: Strategies for Elementary and Secondary School Students. Lynchburg, VA: Lynchburg College. Retrieved from: http://www.lynchburg.edu/sites/defaul t/files/documents/Graduate

Studies/Journal/readingcomprehension.pdf.

10. Indrayani , S.A.(2014). The Effectiveness of Using Mind Mapping in Improving Students' Reading Comprehension of Narrative Text. A Quasi Experimental Study at the Second Grade of SMA Mathla'ul

Huda Parung Panjang-Bogor.

Retrieved from:

http://repository.uinjkt.ac.id/dspace/bit stream/123456789/24484/1/Skripsi\%2 0Sheira\%20Ayu\%20Indrayani\%20Wa termark.pdf

11. Jacobs, D.(2002). Having students articulate the outcomes of mind mapping while reading will improve text comprehension. https://students.education.unimelb.edu .au/LiteracyResearch/pub/

Projects/DJacobs.pdf

12. Khoshsima, H., \& Tiyar, T.F. (2014). The effect of summarizing strategy on reading comprehension of Iranian intermediate EFL learners. International Journal of Language and Linguistics, 2(3), 134139. Retrieved from: http://article.sciencepublishinggroup.c om/pdf/10.11648.j.ij11.20140203.11.pf

13. Kusmaningrum, M. (2016). USING MIND-MAPPING TO IMPROVE READING COMPREHENSION AND WRITING ACHIEVEMENTS OF THE 4TH SEMESTER STUDENTS OF STAIN CURUP. Journal of English Literacy Education, 3(2), 187-201. Retrieved from:

http://ejournal.unsri.ac.id/index.php/je nglish/article/view/3623.pdf.

14. Manning, C.M. (2003). Improving reading comprehension through visual tools. Unpublished MA dissertation. Eastern Nazarene College. Retrieved May 2003 from: http:/www.thinkingfoundation.org

15. Mind Mapping (2011). Retrieved from:

http://ndhsliteracylinks.wikispaces.co $\mathrm{m} /$ file/view/MindMapping. pdf/199758732/MindMapping.pdf

16. Moi, W.A.G. \& Lian, O.L.(2007). Introducing mind map in 
comprehension. Unpublished research paper. Educational research association Singapore. Retrieved from:https://fadhliuia.files.wordpress.c om/2012/10/educational-researchassociation-singapore-20072.pdf.

17. Pranata, M. S. A., \& Junining, E. The Effectiveness of Using Semantic Mapping to Enrich EFL Learner's Reading Comprehension. Journal of Lingkar Widyaiswara, (2), 16-23. Retrieved June 2015 from:

18. http://juliwi.com/published/E0202/Pap er0202 16-23.pdf

19. Roebl, K. M., \& Shiue, C. (2013). Developing reading comprehension skills in EFL university level students. In Proceedings of the Third International Conference on Foreign Language Learning and Teaching, 177-186. Retrieved from: https://www.researchgate.net/profile/ Kevin Roebl/publication/ 313098502 Developing Reading Co mprehension Skills in EFL Universi ty level Students/links/589005cea6fdcc2351be c2ff/

20. Romea, C.( 2015). Level of reading skills among grade 9 students of cdonhssy. https://prezi.com/ 6fanx cdpz/level-of-reading-skillsamong-grade-9- students-of-cdonhssy/

21. Salehi, A. D., Jahandar, S., \& Khodabandehlou, M. (2013). The impact of concept mapping on EFL student's reading comprehension. Indian Journal of Fundamental and Applied Life Sciences, 3(3), 241-250

22. San Risqiya, R. (2013). The use of mind mapping in teaching reading comprehension. ELTIN JOURNAL, Journal of English Language Teaching in Indonesia, 1(1). Retrieved from: http://ejournal.stkipsiliwangi.ac.id/ind ex.php/eltin/article/view/54

23. Siriphanich, P.(2010). Use of Mind Mapping to Improve Reading Comprehension of EFL University Students. Faculty of Liberal Arts, Prince of Songkhla University, Hatyai Campus. The Royal Golden Jubilée International Seminar Series LXX 191-192. Retrieved March 17, 2010 from: http://sichon.wu.ac.th/file/arts20100317-110706-7UXYf.PDF.

24. Snow, C. (2002). Reading for understanding: Toward an $R \& D$ program in reading comprehension. Rand Corporation. Retrieved from: https://s3.amazonaws.com/academia.e du.documents/ 38406216/Reading for understanding Toward an R D program in readi ng comprehension.pdf?

25. Suryani, L. (2015). IMPROVING STUDENTS' READING SKILLS BY USING THE MIND MAP TECHNIQUE AT SMA $\mathrm{N}$ 1 KRETEK IN THE ACADEMIC YEAR OF 2013/2014. Yogyakarta: State University of Yogyakarta. Retrieved from: http://eprints.uny.ac.id/16031/1/Lani\% 20Suryani\%2008202241009.pdf

26. Tabrizi, A. R. N., \& Esmaeili, Z. (2016). The Effect of Mind Mapping on Reading Comprehension Ability of Iranian Intermediate Efl Learners. Modern Journal of Language Teaching Methods,6(1), 205.

27. van den Broek, P., \& Espin, C. A. (2012). Connecting cognitive theory and assessment: Measuring individual differences in reading comprehension. School Psychology Review, 41(3), 315. Retrieved from: https://www.researchgate.net/publicati on/285908866 Connecting cognitive theory and assessment $\mathrm{Me}$ 
asuring_individual_differences_in_rea ding_comprehension

28. Williams, M.H.(2008). Physical webbing: Group construction of threedimensional mind maps to build understanding and knowledge. Retrieved

from:http://services.eng.uts.edu.au/use rpages/brucem/public_html/icel2/1/ice 1/Papers/35 Paper.pdf

29. Wirda,W. Sulaiman, H.Wahyudin (2014). USING MIND MAPPING TECHNIQUE TO IMPROVE READING COMPREHENSION OF

\section{THE SECOND YEAR}

STUDENTS. ELTS JOURNAL, 2(3)

Retrieved from:

http://widyanisolihat.blogspot.com.eg/ 2017/04/using-mind-mappingtechnique-to-improve 11.html

30. Yunus, M. M., \& Chien, C. H. (2016). The use of mind mapping strategy in Malaysian university English test (MUET) Writing. Creative Education, 7(04), 619. Retrieved from: http://www.scirp.org/journal/ce 